\title{
Tempo
}

http://journals.cambridge.org/TEM

TEM $\rho O$

Additional services for Tempo:

Email alerts: Click here

Subscriptions: Click here

Commercial reprints: $\underline{\text { Click here }}$

Terms of use : $\underline{\text { Click here }}$

\section{PETER MAXWELL DAVIES IN THE 1950S: A CONVERSATION WITH THE COMPOSER}

Nicholas Jones

Tempo / Volume 64 / Issue 254 / October 2010, pp 11 - 19

DOI: 10.1017/S0040298210000380, Published online: 13 October 2010

Link to this article: http://journals.cambridge.org/abstract_S0040298210000380

How to cite this article:

Nicholas Jones (2010). PETER MAXWELL DAVIES IN THE 1950S: A CONVERSATION WITH THE COMPOSER. Tempo, 64, pp 11-19 doi:10.1017/S0040298210000380

Request Permissions : $\underline{\text { Click here }}$ 


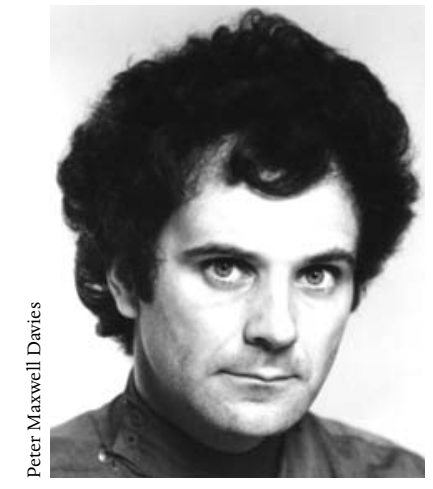

\section{PETER MAXWELL DAVIES IN THE I95OS: A CONVERSATION WITH THE COMPOSER}

\author{
Nicholas Jones
}

The 1950s was a particularly important decade for Peter Maxwell Davies. It was the period when he established the fundamental elements of his compositional technique; the decade in which he composed his first acknowledged works; and a time, coinciding with his emergence as a composer of substance, when he travelled to Darmstadt, Paris and Rome. It was also the period that witnessed the publication of two of his own articles, and the decade in which his interest in early music particularly plainchant - and Indian classical music began to influence his own compositional thinking and resulting works.

Given the apparent significance of this decade, then, it is perhaps surprising that it has received relatively little scholarly attention. Indeed, although Davies's published compositions from the 1950s - Sonata for Trumpet and Piano (1955), Five Pieces for Piano (1955-6), Alma Redemptoris Mater (1957), St Michael (1957) and Prolation (1958) - have benefited from close examination, ${ }^{1}$ it has only been within the last year or so that significant steps have been made to bring this formative period more sharply into focus. ${ }^{2}$

The following is an edited transcript of a conversation which took place in London on 21 January $2008 .{ }^{3}$ It addresses several specific issues, including the composer's time as a student in Manchester; the part that Messiaen played in Davies's development as a composer; the influence of Indian music and plainchant on his own compositions; and Davies's early writings. Loquacious, articulate and helpful as ever, Davies needed no real prompting from me to start the discussion.

PMD: First thought: there is a piece which is at home in Orkney on a music stand, which I wrote in 1949; it's a piano piece called Parade. There are so many things in that piece that are absolutely crucial to everything that I wrote in the next ten or so years. And I was still a schoolboy when I wrote it.

\footnotetext{
${ }^{1}$ See David Roberts, 'Techniques of Composition in the Music of Peter Maxwell Davies' (PhD thesis, Birmingham University, 1985) and Richard McGregor, 'Peter Maxwell Davies: The Early Works', Tempo, 160 (1987), pp. 2-7.

2 See Nicholas Jones, 'The Writings of a Young British Composer: Peter Maxwell Davies in the 1950s' in Kenneth Gloag and Nicholas Jones (eds.), Peter Maxwell Davies Studies (Cambridge: Cambridge University Press, 2009), pp. 21-44; and Philip Rupprecht, "'Something Slightly Indecent": British Composers, the European Avant-garde, and National Stereotypes in the 1950s', Musical Quarterly, 91/3-4 (Fall-Winter 2008), pp. 275-326.

3 Text and dates in square brackets are editorial.
} 
NJ: In 1949 you were, what, fifteen years old?

PMD: Yes, that's right. The piece has lots of rhythmic quirks, lots of use of linear and harmonic material which recurs and recurs in the music of that period. Until this moment I have never thought about publishing the piece, but it works perfectly well as a piano piece.

$\mathrm{NJ}$ : And if it's on your stand then it must still hold some significance for you?

PMD: I found it three or four years ago - it was stacked away with some other music. I found it again recently and played through it and put it up on the stand. It's a beautiful manuscript! But the first piece that I really acknowledge from the fifties was the Trumpet Sonata - that was such a breakthrough. And I think that it was very much influenced by the liberating experience of meeting Sandy [Alexander] Goehr and Harry [Harrison] Birtwistle at the College. ${ }^{4}$ They were questioning everything, and it was as if they had opened doors, and I went through these doors. I can remember going along, in what must have been late 1954, to Alexander Goehr's flat in Withington and there was this piano there and I played through this piece to him and Harry, and I can remember Sandy Goehr's attitude to this was a bit querulous - I don't think he really approved - and he said, 'It sounds like a lot of boxes falling on your head!'

NJ: What an odd way of putting it!

PMD: Well, I suppose in those days it did. We did the Trumpet Sonata first at a concert in the Arthur Worthington Hall at the University at Manchester - John Ogdon played the piano and Gary [Elgar] Howarth the trumpet - and I had quite a row with our professor, Humphrey Procter-Gregg. ${ }^{5}$ I was not studying composition with him anymore - I had been kicked out of his composition class and I had a postcard from him saying (and I still have this): 'What is this I hear about a piece by you being performed in the Arthur Worthington Hall? I've not been asked for permission!' And so I probably almost destroyed my chances ever of having a degree from Manchester University - I went storming into his office saying: 'You're not my composition teacher, this is nothing to do with you, and we're going to play it.' And I remember ProcterGregg announcing to the University choir: 'There's a concert tomorrow night at the Arthur Worthington Hall, but it's a very poor prospect for your degree if you're seen attending it.'

NJ: Oh, dear!

PMD: Yes, the knives were out!

NJ: Why did you get thrown out of his composition class? Was it merely a clash of personalities?

PMD: No, I was interested in people like Bartók and Stravinsky and he wouldn't have that. He said that these people were irrelevant and Delius was the future of music!

\footnotetext{
${ }^{4}$ Royal Manchester College of Music, now the Royal Northern College of Music.

${ }^{5}$ Humphrey Procter-Gregg (1895-1980), Professor of Music, Manchester University, $1954-62$.
} 
NJ: And I gather he wasn't interested in early music either?

PMD: No, he wasn't. He used to say: 'Don't take any notice of music written before 1550, it's dangerous'. And when it came to my degree Procter-Gregg did his damnedest to stop it, but fortunately there was an external examiner there, Dr Andrews from Oxford, who insisted that I got an Honours degree. ${ }^{6}$ God, that man [Procter-Gregg] loathed me! I don't blame him - I hated everything he stood for.

NJ: How many people attended the Arthur Worthington Hall concert?

PMD: We had an audience of six. So that was the first performance of my Trumpet Sonata, Sandy Goehr's pieces for clarinet and piano [Fantasias, op. 3 (1954)], and the first performance in Manchester of the Webern Variations [op. 27] and selections from Vingt regards sur l'enfant Jésus by Olivier Messiaen. It was further complicated by the fact that there was a society based in the College called the Manchester New Music Society, and we called ourselves New Music Manchester.

NJ: And what kinds of things did the Manchester New Music Society perform?

PMD: At their most outrageous a sonata by Hindemith, but mostly Cyril Scott! ! They also did some Thomas Pitfield, who taught composition at the College. ${ }^{8}$

NJ: The other composition class at the College was run by Richard Hall. ${ }^{9}$ When you got thrown out of Procter-Gregg's class, did you transfer to Hall's composition class?

PMD: No, I just got on with composition by myself. There were plenty of books in the Henry Watson Music Library, and I borrowed scores. I was beginning to be able to read German fairly well and they had things in German - like [Schoenberg's] Harmonielehre and Berg's analysis of the First Chamber Symphony by Schoenberg - and I went through those. And so I think I was very largely self-taught, until in 1957 I went to Italy to study with [Goffredo] Petrassi, and he taught me a great deal.

NJ: Yes, absolutely. But to return to Richard Hall for the moment, did you ever study with him in an official capacity?

PMD: I was on a Lancashire County scholarship to read music on a joint course at the University and the College, so I had to go through the University channels (and I went past Procter-Gregg), but I went to Hall not for composition, but for orchestration. So I went along and Harry and Sandy were there and we sat in and just discussed things and talked, and that was very important.

NJ: Did you show Hall any of your compositions?

PMD: Yes, I did actually, and he made some very constructive comments. But that must have happened maybe twice.

\footnotetext{
${ }^{6}$ Herbert Kennedy Andrews (1904-1965), musicologist, teacher, organist and composer, author of The Oxford Harmony, Vol. 2 (London: Oxford University Press, 1950) and books on Palestrina (1958) and Byrd (1966).

${ }^{7}$ Cyril Scott (1879-1970), English composer, writer and pianist.

${ }^{8}$ Thomas Pitfield (1903-99), Professor of Composition, Royal Manchester College of Music, 1947-73.

${ }^{9}$ Richard Hall (1903-82), Professor of Composition, Royal Manchester College of Music, $1938-56$.
} 
NJ: What was your opinion of Hall?

PMD: He was absolutely upright, outrageously honest, and against the establishment. He bent over backwards just to talk to Birtwistle, Ogdon, Goehr and I. And just to talk with somebody who was interested in what you had to say ... No one else would!

NJ: The situation at the time really was as dire as this?

PMD: Yes, it was. Goehr, Birtwistle, Ogdon, Howarth, I and a few others were known as being totally against the University and College establishment - which we were! We learnt very early on what the establishment one was against really was, and how ridiculous it was, and the sheer strength and vitality of what we stood for. We thought that this was the English establishment at its absolute worst and we had a mission to replace it. Whether we did that or not, I don't know - it doesn't matter - but I think we did put it into some kind of perspective.

NJ: Did you ever consider yourselves as constituting a 'school'?

PMD: No, no. It was only ever two concerts, one in Manchester and one in London [St James's Square, 9 January 1956] - and one at the York Festival, I think of ' 56 - and that was it.

NJ: And the rest is history ...

PMD: Well, pseudo-history!

NJ: At this time, 1956, you had published in The Score magazine your first article, 'The Young British Composer'. This was followed three years later by another in The Listener. ${ }^{10}$ Murray Schafer has described these early writings as 'pugilistic'. ${ }^{11}$ Would you agree with this description?

PMD: I haven't thought about it for a long time, but I think he was probably right. I was so disgusted with the establishment which was blocking so much that was interesting. You couldn't get anything done at the BBC, for instance, not until William Glock took over [in 1959]. Sandy Goehr and I eventually had a piece done on the BBC but it wasn't through the Music Department, it was through Documentation. I've forgotten the details (you'll have to ask Sandy), but they did my Five Piano Pieces [op. 2] and Sandy's Piano Sonata [op. 2 (1951-2)], played by Margaret Kitchin. But, yes, it was all done through Documentation because the so-called Music Department blocked everything.

NJ: What did you set out to achieve in these early articles?

PMD: I don't think I set out to achieve anything. I was just bloody furious!

NJ: Your anger certainly comes out in the writing. You highlight some key themes in these articles: the lamentable state of music education; inadequate training for composers; the value of analysis and compositional technique. All of these things have stayed with you throughout your life.

PMD: Yes. I remember from my own experience at Manchester, and from talking to students at the Royal Academy [of Music] at the time (such as Richard Rodney Bennett), that rigorous training in technique was unknown. And in 1951, 52 and 53, I'd been to

\footnotetext{
10 'The Young British Composer', The Score, 15 (March 1956), pp. 84-5 and 'Problems of a British Composer Today', The Listener, 62 (8 October 1959), pp. 563-4.

${ }_{11}$ Murray Schafer, British Composers in Interview (London: Faber and Faber, 1963), p. 173.
} 
Germany and talked to students, for instance, from Hamburg who had least got a rigorous training in things like counterpoint, fugue, and basic analysis. We didn't. We got fugue out of a book by Kitson, and orchestration out of a book by Forsyth. ${ }^{12}$ I thought that all of this was already so old fashioned! And I discovered for myself the four volumes of orchestration by Koechlin, the French composer, and they're much, much more exciting. ${ }^{13}$ I still have them there on my shelf and I will refer to them when I want to know if a double bass can do a certain harmonic or not. But sheer technique was not even touched on at Manchester. It was more of a matter of inspiration; how you feel. And the god who was held up to us by Humphrey ProcterGregg was, of course, Delius and I've always loathed his music ever since - perhaps coming around to it a little bit more - but it puts you off for life!

No: I'm guessing that you looked at Messiaen's Technique de mon langage musical?

PMD: Oh yes. I had a wonderful first edition in French which somebody stole - I took it to Dartington Summer School of Music in, it must have been, 1956, and I went to look for it and it was gone!

NJ: How well did you know Messiaen's music at this time, 1955-6?

PMD: I knew the Vingt regards - I'd taken it out of the Henry Watson Music Library and played it, as did John Ogdon. I knew the Turangalîla-Symphonie through Sandy Goehr - he had a score, and his father had conducted it. And so I knew what was available until then, including the 1930s pieces, quite well. So, yes, I think we were all very familiar with his music.

NJ: You mention that Walter Goehr had conducted the TurangalîlaSymphonie. In April 1954 he gave the London concert première of the piece, an event that both Birtwistle and Alexander Goehr attended. Did you also travel down from Manchester to attend the concert?

PMD: No, I heard it on the radio [the Third Programme]. I know that was one of Harry Birtwistle's 'epiphany' moments, where he describes going up in a lift and hearing the percussion and thinking: Well, that's percussion liberated for all its life!

NJ: And how did it affect you?

PMD: I thought: This is wonderful; this is a liberation.

NJ: During your time at Manchester you made two trips to Darmstadt, in 1956 and 57. In what ways did these trips influence your thinking at the time?

PMD: I realized that there was another establishment, and that was the 'Mafiosi' of new music. And anything that didn't conform to their standards was just as dangerous as anything that didn't conform to the standards of the British music establishment. And what they [the new music establishment] called 'the new', even in 1956, was dated. And being interested in William Byrd and John Dunstable, and Mozart, Haydn and Beethoven, gave me a huge advantage over these people because they had severed all of their roots, apart from Webern. I thought: Yes, wonderful,

\footnotetext{
${ }^{12}$ C.H. Kitson, Studies in Fugue (Oxford: Clarendon Press, 1909); Cecil Forsyth, Orchestration (London: Macmillan 1914).

${ }^{13}$ Charles Koechlin, Traité de l'orchestration (Paris: Eschig, 4 vols, 1954-9).
} 
I can learn a great deal from this, but underneath there is no root going into the ground, and any plant that doesn't have a root, with a bit of fertilizer, can flourish for so many hours or days, but then that's the end of it. And I think I realized that there was an establishment in German radio stations, and a whole German organization of how new music went, that this was as negative as the British music establishment, but of a completely different sort. But I tried to make something constructive out of it - learn what I possibly could, particularly from Stockhausen - and Luigi Nono, and Bruno Maderna, and Luciano Berio became very good close friends. But I still had this attitude of: Yes, learn what you can, but beware.

NJ: This attitude really comes out in your 1959 article for The Listener. You seem to be quite happy to distance yourself from the Continental avant-garde.

PMD: 'Avant-garde' - what are you ahead of? I think I could sum it up by saying, Ex nihilo nihil fit ('out of nothing, nothing comes'). And they cut away their roots to such an extent that I thought: This is very dangerous. And I can understand it if you lived in Nazi Germany or Fascist Italy, if you wanted to cut that completely away because it was so utterly repulsive. Perhaps here [in Britain] we had an advantage because I didn't feel so antagonistic towards those writing in the 'established' musical world, like Ben Britten or Vaughan Williams or whoever, and I think we had a more constructive attitude to our immediate predecessors, although it was very, very critical.

NJ: You mention Britten. What impact did Peter Grimes have on you when you heard it for the first time?

PMD: I first heard it in, what, 1949. It had a huge impact; it was a huge inspiration - that this was possible in Britain. Obviously one thought that one would not be able to emulate or imitate Britten's style, but it was an inspiration. Particularly in Taverner [Davies's first opera (1962-68, partly reconstructed 1970)], I think I learnt a lot from Ben Britten.

NJ: So it took a certain amount of time for his 'influence' to come through?

PMD: Yes. I think in the fifties there was a slight reaction against Britten because he was so tonal.

$\mathrm{NJ}$ : As part of your degree you wrote a thesis on Indian classical music. ${ }^{14}$ It's a remarkable piece of research for its time - innovative, one might say. Who was your supervisor?

PMD: I didn't have one!

NJ: So you wrote it completely on your own?

PMD: Yes, no supervisor.

$\mathrm{NJ}$ : Well, that's quite extraordinary! But how on earth did you get Humphrey Procter-Gregg to come round to the idea of you writing a thesis on such a theme?

PMD: I met some Indian students, and they played [Indian classical music], and I thought that here was something that ProcterGregg knows nothing about. And having been thrown out of the

\footnotetext{
${ }_{14}$ 'An Introduction to Indian Music', 2 vols. (Mus.Bac. thesis, University of Manchester, 1956).
} 
composition class I had to write a thesis, so I thought that this was something I could write my thesis on. I was actually very clever because I got my father to go and see him and say that I was very interested in Indian music - and my father persuaded him. I thought that this was wonderful: he [Procter-Gregg] knew nothing about it and so I could get away with murder! But Indian music was something that I was genuinely interested in. You could buy, for instance, from second-hand stores 78rpm records, and I've still got some. I couldn't understand the writing on them because it was in Hindi or Urdu, but I played these things and I liked them very much.

NJ: So your initial interest was triggered by these records and your contact with Indian students at the University. You then came to the books of Alain Daniélou?

PMD: Yes, and Fox Strangways. ${ }^{15}$

NJ: And what about Messiaen? Did his music have any influence on your decision to choose Indian music as the subject of your thesis?

PMD: Oh yes. As I've already explained, I read his Technique de mon langage musical, and it did have a big influence, but I realized that Messiaen didn't know much about Indian music (dare I say, quietly)! He took his information from a thirteenth-century writer called Carngadeva, and I don't think Messiaen had any contact with Indian music as it was then practised 50 years ago; it was all theoretical, on paper.

NJ: But I'm guessing that Messiaen knew Daniélou?

PMD: I don't know; I have no idea. You'll have to do some research on that ${ }^{16}$ But Messiaen's music was so hermetically sealed. And fine, it did produce some wonderful stuff, but I don't think it had too much to do with Indian music as it was practised.

NJ: Did you go to Paris to see Messiaen teach?

PMD: Yes, I did. I sat in on several of Messiaen's classes when Sandy Goehr was a student. ${ }^{17}$

NJ: Did you ever go before then?

PMD: No. (Well, obviously I'd been to Paris, but I didn't go to the Conservatoire.) I just eavesdropped - I think that is the right word, because I didn't participate, I didn't say a word - whilst Alexander Goehr, Gilbert Amy and the rest of them were all studying with Messiaen. I think I learnt a lot. And one thing I do remember - it was then the old Paris Conservatoire in rue de Madrid, and Messiaen taught in the Salle Gounod - and I was introduced to Messiaen by Alexander Goehr, and Messiaen said, 'Well, if you'd like to come and sit in then that's fine. We meet in the Salle Gounod, mais ça n'est pas de ma faute!' - which I thought was a lovely comment on Gounod.

15 A.H. Fox Strangways, The Music of Hindostan (Oxford: Clarendon Press, 1914); Alain Daniélou, Northern Indian Music, Vol. I: Theory and Technique (London: Christopher Johnson; Calcutta: Visva Bharati, 1949) and Vol. II: The Main Ragas (London: Halcyon Press, 1954).

16 John Morgan O'Connell and Nigel Simeone have both confirmed to me that Messiaen and Daniélou did in fact know each other. Their association, especially the extent of Daniélou's influence on Messiaen, if any, would indeed benefit from careful examination.

17 Alexander Goehr was a registered member of Messiaen's class at the Paris Conservatoire in the academic year 1955-6. For Goehr's own account of his time in Paris, see 'The Messiaen Class' in Derrick Puffett (ed.), Finding the Key: Selected Writings of Alexander Goehr (London: Faber and Faber, 1998), pp. 42-57. 
NJ: How many of Messiaen's classes did you visit?

PMD: I went to several of his classes when I was staying in Paris with Sandy and his then wife. I remember on one occasion that Messiaen was talking about [Mussorgsky's] Boris Godunov, and he took from the Prelude the two chords on which it's based and related them to [Debussy's] Pelléas et Mélisande. He was saying how much Debussy must have learnt from Mussorgsky. I thought that was interesting. Then he talked about Beethoven 5 , and that was not very constructive. I remember Sandy Goehr putting his hand up and saying, 'Mais Maître, vous ne connaissez pas le livre de Heinrich Schenker sur Symphonie numero Cinq de Beethoven?' And Messiaen replied: 'Schenker? Schenker? Qui est-ce Schenker? Je ne le connais pas.' And it was extraordinary that Messiaen was playing on the piano a few chords from Beethoven 5 and saying, 'Ça c'est joli, n'est-ce pas?' - but they had no relation to anything else; they were purely decorative. ${ }^{18}$

$\mathrm{NJ}$ : Around this time you wrote several pieces that were consciously based on your study of Indian music. One of them was the original version of Stedman Doubles [1955]. What were the others?

PMD: There was a string quartet, which has now gone, but a fragment of it still survives [Quartet Movement (1952)] - it was reconstructed from some sketches and is still played. This is so influenced by Indian music - it sounds like a Europeanized kind of Indian music. But I think it [the influence of Indian music] has permeated deeper than that; it's just there, through everything.

$\mathrm{NJ}$ : Can you say some more about this? Just how important is it, do you think?

PMD: Well, I don't think of it anymore, but it was a way of thinking about line and variation and transformation - the way a line without harmony or whatever, just a tonic underneath it, transforms over a long period. And you can have, against a regular rhythm, something that is so exciting which contradicts that. And there's a wonderful moment when it all comes together. I was in India in 1966 and I experienced this under trees and everyone shouts, 'Acha! Acha!' - Good! Good! - when the tablā and soloist actually come together. And I thought: This is music where people are really listening to what the other is doing.

NJ: You make reference here to the tonic. In your thesis you seem to be very interested in the intervallic relationships that exist in the rāga scale, namely between the tonic, the vādi (the note most used when playing), and the samvādi (the note very often, but not always, a fourth or fifth away from the vādī). The idea of having a tonic and 'companion' note or notes, which are not necessarily a fourth of fifth away from the tonic, is indeed interesting when one relates this to some of your own music later on, particularly from the First Symphony (1973-6) onwards, which uses 'tonics' and 'dominants'. ${ }^{19}$

PMD: Yes, and these notes need not be the usual tonic and dominant. It was quite a departure, a realization that it need not be a perfect fourth below or perfect fifth above. It was a very liberating experience.

\footnotetext{
${ }^{18}$ Cf. Goehr, 'The Messiaen Class', pp. 47-8 and 51-2.

19 For a fuller discussion of tonics and dominants in Davies's music, see Nicholas Jones, 'Dominant Logic: Peter Maxwell Davies's basic unifying hypothesis', The Musical Times, 143 (Spring 2002), pp. 37-45.
} 
NJ: It is indeed tempting, then, to understand your concept of tonality as a synthesis of Indian, medieval and 19th-century techniques.

PMD: Yes, but in relation to what one also knows as the dominant being a fourth below. There's a tension between the two, and I hope that I use that constructively.

NJ: To go back to the original version of Stedman Doubles, and the first movement in particular: there are enough potent indicators in the opening ten bars to suggest that this section can be understood as your own interpretation of an ālāp, the opening section of a rāga.

PMD: Yes, it's an ālāp - spot on!

NJ: In your thesis you analyze in meticulous detail an Indian ālāp melody. All of the qualities you highlight there are in evidence in these opening ten bars, especially in relation to the melodic line, played by the clarinet, and the way in which every interval has an acute sense of deliberation.

PMD: When I got to Rome [in 1957] I heard the Greek equivalent of plainsong at the Grottaferrata Monastery near Rome, where you really did feel as though they were 'pulling out' the intervals, and every interval was set against the tonic - which didn't always sound - and you listened to it so carefully over that long period. And it was stretched out and you really had to understand the relationship of every note to that tonic. And I thought: Yes, I learnt about that in my study of Indian music, but this brings it to absolute crystal clarity. And it's something that I hope is there in the choral music or whatever that I wrote after that.

NJ: Is it possible, then, to map a rāga structure onto the entire first movement of Stedman Doubles?

PMD: Yes, you could. ${ }^{20}$

$\mathrm{NJ}$ : What other pieces of yours would you say are influenced by the techniques that you discovered in Indian music? For me, the opening 20 minutes of Worldes Blis (1966-9) has something of the ālāp about it.

PMD: Yes, and that goes right back to my study of Indian music and my later study of Aboriginal music through Cath Ellis, ${ }^{21}$ but also to plainsong - the way that plainsong works over a very long period. And when I was in Rome in the fifties I would go up to the Benedictine monastery on the Aventine with my Liber Usualis, and I knew exactly what they were doing that day - I'd prepared it all - and they just did their plainsong. I just sat there, enjoyed it, and realized that this was the best music I'd heard in my life. And, of course, you'd never get to that state of purity, but it can influence you very, very strongly. And there's no entertainment; it just is itself. And you're either with it or you're not, but there's something beyond entertainment: it really goes into the very core of one's own existence.

\footnotetext{
${ }^{20}$ For a discussion of Stedman Doubles and its close relationship to ideas explored in Davies's thesis, see Nicholas Jones, 'The Writings of a Young British Composer', pp. 29-44.

${ }^{21}$ Catherine J. Ellis, Aboriginal Music Making: A Study of Central Australian Music (Adelaide: Libraries Board of South Australia, 1964). Ellis introduced Davies to Aboriginal music in 1966 when he was Composer-in-Residence at Adelaide University.
} 